\title{
PIJAT BAYI DALAM MENINGKATKAN TUMBUH KEMBANG BAYI
}

\author{
Rika Andriyani, Novita Lusiana
}

\begin{abstract}
Baby massage is a touch and massage on the baby after birth can provide assurance of continuous body contact that can maintain a feeling of security in the baby. It is hoped that community service objectives can increase the knowledge and skills of cadres and toddlers' mothers about infant massage. Method Activities carried out by providing health education (counseling) about infant massage, demonstrations of the implementation of infant massage. The location of the activity is carried out at the posyandu which is located in RW 10, Tangkerang Labuai District. Results of the implementation of increased knowledge and understanding of cadres and mothers of toddlers about infant massage, seen from the ability of mothers and cadres in answering questions raised by the speakers. Increasing the skills of mothers under five in infant massage, so that it is possible for participants to be able to massage their babies by themselves, only $50 \%$ of mothers who receive infant massage training do it back at home regularly and continuously. It is recommended that the puskesmas hold similar activities for groups of mothers under five at different places, to make this infant massage a routine activity at Posyandu.
\end{abstract}

Key Word : Baby Massage, Growth and Development

\begin{abstract}
ABSTRAK
Pijat bayi merupakan Sentuhan dan pijat pada bayi setelah kelahiran dapat memberikan jaminan adanya kontak tubuh berkelanjutan yang dapat mempertahankan perasaan aman pada bayi. Tujuan pengabdian masyarakat diharapakan dapat menambah pengetahuan dan keterampilan kader dan ibu balita tentang pijat bayi. Metode Kegiatan yang dilakukan dengan cara memeberikan pendidikan kesehatan (Penyuluhan) tentang pijat bayi, demonstrasi pelaksanaan pijat bayi. Lokasi kegiatan dilaksanakan di di posyandu yang terletak di RW 10 Kecamatan Tangkerang Labuai. Hasil Pelaksanaan meningkatnya pengetahuan dan pemahaman kader dan ibu balita tentang pijat bayi, dilihat dari kemampuan ibu bayi dan kader dalam menjawab pertanyaan yang diajukan oleh pemateri. meningkatnya keterampilan ibu balita dalam memijat bayi, sehingga dimungkinkan peserta dapat melakukan pijat bayi sendir, hanya $50 \%$ ibu yang mendapatkan pelatihan pijat bayi yang melakukan nya kembali dirumah secara rutin dan berkesinambungan. Disarankan kepada pihak puskesmas untuk mengadakan kegiatan serupa pada kelompok ibu balita pada tempat yang berbeda, untuk dapat menjadikan kegiatan pijat bayi ini menjadi kegiatan rutin di Posyandu.
\end{abstract}

Kata Kunci : Pijat Bayi, Tumbuh kembang

\section{. PENDAHULUAN}

Pijat adalah terapi sentuh paling tua yang di kenal manusia dan paling
populer.Pijat adalah seni perawatan kesehatan dan pengobatan yang telah di praktekkan sejak abad-abad silam. Bahkan, 
diperkirakan ilmu ini telah dikenal sejak awal manusia di ciptakan ke dunia, mungkin karena pijat berhubungan sangat erat dengan kehamilan dan proses kelahiran manusia (Roesli,2009).

Pijat dapat di lakukan pada semua umur termasuk pada bayi. Sentuhan dan pijat pada bayi setelah kelahiran dapat memberikan jaminan adanya kontak tubuh berkelanjutan yang dapat mempertahankan perasaan aman pada bayi (Roesli,2009). Bayi baru lahir merupakan individu yang sedang mengalami trauma kelahiran serta harus dapat melakukan penyesuaian diri dari kehidupan intrauteri dan eksrtauterin. Bayi baru lahir normal adalah bayi yang baru lahir pada usia kehamilan 37-42 minggu dan berat badan 2.500-4000 gram (Vivian,2010).

WHO (1961) menambahkan bahwa bayi prematur adalah bayi yang lahir sebelum usia kehamilan 37 minggu dengan berat lahir dibawah 2500 gram (Fadlun,2012). Bayi- bayi prematur yang di pijat secara teratur setiap hari menunjukkan perkembangan fisik dan emosional yang lebih baik ketimbang pada bayi-bayi yang tidak dipijat. Berat badan bayi prematur yang dipijat mengalami peningkatan berat badan 20 hingga 40 persen di bandingkan bayi yang tidak di pijat (Roesli, 2008).

Hal ini telah dibuktikan oleh para ahli di Fakultas Kedokteran Universitas Miami pada tahun 1986 yang dipimpin oleh Tiffany M Flied PhD. Juga dikatakan bahwa bayi-bayi yang di pijat selama 5 hari saja, daya tahan tubuhnya akan mengalami peningkatan sebesar 40 persen di bandingkan bayi- bayi yang tidak di pijat (Rina, 2010).

Penelitian pada bayi cukup bulan yang berusia 1-3 bulan, yang di pijat selama 15 menit, 2 x seminggu selama 6 minggu di dapatkan kenaikan berat badan yang lebih dari konrtol. Tidak hanya itu pijat bayi bermanfaat untuk meningkatkan sistem kekebalan tubuh, mengubah gelombang otak secara positif, memperbaiki sirkulasi darah dan pernafasan, meransang fungsi pencernaan dan pembuangan, meningkatkan hubungan batin antara orangtua dan bayi nya, dan meningkatkan volume air susu ibu (Roesli,2009).

Peraturan Menteri Kesehatan Republik Indonesia Nomor 369/MENKES/SK/2007 tentang Standar Profesi Bidan menyebutkan bahwa bidan mempunyai kewenangan untuk melaksanakan pemantauan dan menstimulasi tumbuh kembang bayi dan anak. Salah satu bentuk stimulasi tumbuh kembang yang selama ini dilakukan oleh masyarakat adalah dengan melakukan pijat bayi (Yanti,2010).

Di Indonesia ilmu ilmu pijat bayi tradisional sudah lama di kenal, bahkan sampai sekarang pun masih di lakukan oleh dukun pijat bayi di daerah-daerah. Maka disini pijat bayi dilakukan oleh ibu, ayah, atau anggota keluarga si bayi. Penting di ketahui juga bahwa pijat bayi di sini di peruntukkan bagi bayi yang sehat (Roesli,2007).

Berdasarkan data yang di dapat oleh peneliti dari Dinas Kesehatan Kota Pekanbaru tahun 2013, dari 20 Puskesmas yang ada di Kota Pekanbaru,/ salah satunya adalah PusKesMas Harapan Raya yang terdapat beberapa posyandu. Posyandu mempunyai layanan yang berperan penting dalam masyarakat untuk memperoleh atau mendapatkan informasi dan pelayanan kesehatan dasar terutama berkaitan dengan penurunan Angka Kematian Ibu (AKI), Angka Kematian Bayi (AKB), dan Angka Kematian Balita (AKABA). Informasi yang diperoleh 
jumlah bayi yang terdapat di Kelurahan Tangkerang Labuai terdapat 404 bayi, untuk di posyandu yang terletak di RW 10 Kecamatan Tangkerang Labuai, dengan jumlah bayi sebanyak 43 orang dan tidak pernah mendapatkan informasi ataupun kegiatan yang berkaitan dengan pijat bayi.

Berdasarkan wawancara dengan pihak puskesmas dan posyandu maka disepakati cara penyelesaian persoalan diatas dengan melakukan pelatihan terhadap kader Posyandu dan ibu yang memiliki bayi.

Berdasarkan data diatas, maka dirasa perlu dilakukan pembinaan kader dan masyarakat khusunya ibu yang memiliki bayi pada kelompok Posyandu yang akan diintegrasikan dalam kegiatan pengabdian masyarakat di Kelurahan Tangkerang Labuai Kecamatan Bukit Raya.

\section{METODE KEGIATAN}

\section{A. Kerangka Pemecahan Masalah}

Berdasarkan Informasi yang diperoleh bahwa jumlah bayi yang terdapat di Kelurahan Tangkerang Labuai terdapat 404 bayi, untuk di posyandu yang terletak di RW 10 Kecamatan Tangkerang Labuai, dengan jumlah bayi sebanyak 43 orang dan tidak pernah mendapatkan informasi ataupun kegiatan yang berkaitan dengan pijat bayi. Berdasarkan hal tersebut maka perlu dilakukan pendidikan kesehatan kepada Kader dan ibu bayi untuk dapat meningkatkan tumbuh kembang bayi secara optimal melalui kegiatan Pijat bayi.

\section{B. Rancangan Evaluasi}

Evaluasi dilaksanakan dalam bentuk: mengulas kembali materi dengan diskusi dan tanya jawab dan membahas penyelesaian masalah.

Indikator pencapaian : 1) Kader dan ibu bayi mampu menjawab pertanyaan yang diajukan oleh pemateri berkaitan dengan pijat bayi (minimal $70 \%$ dari jumlah pertanyaan terjawab), 2) Kader dan ibu bayi mampu melakukan pijat bayi tanpa melihat panduan.

\section{Metode Kegiatan}

Metode kegiatan yang dilakukan dalam kegiatan pengabdian masyarakat ini adalah dalam bentuk pendidikan kesehatan (Penyuluhan )tentang Pijat Bayi, dan demonstrasi pelakaanaan Pijat Bayi. Seluruh kegiatan dilakukan dengan pendekatan partisipatif yang artinya peserta dituntut aktif selama kegiatan berlangsung.

\section{HASIL DAN PEMBAHASAN}

\section{A. Hasil Pelaksanaan}

Berdasarkan wawancara, tanya jawab dan pengamatan langsung selama kegiatan berlangsung, kegiatan pengabdian pada masyarakat ini memberikan hasil sebagai berikut: 1) Meningkatnya pengetahuan dan pemahaman kader dan ibu balita tentang pijat bayi, dilihat dari kemampuan ibu bayi dan kader dalam menjawab pertanyaan yang diajukan oleh pemateri. 2) meningkatnya keterampilan ibu balita dalam memijat bayi, sehingga dimungkinkan peserta dapat melakukan pijat bayi sendiri. 3) Meningkatnya keterampilan kader dalam memijat bayi, sehingga dapat terus memberikan pelatihan kepada ibu ibu yang baru memiliki balita untuk memijat bayi. 4) Adanya peningkatan penambahan berat badan pada balita sebanyak $50 \%$ dari jumlah ibu yang sudah mendapatkan pelatihan tentang pijat bayi.

\section{B. Pembahasan}

Sejumlah kader dan ibu balita di Posyandu yang berada di RW 10 Kecamatan Tangkerang Labuai mendapatkan penyuluhan dan pelatihan tentang pijat bayi. Pijat bayi merupakan sentuhan dan pijat pada bayi setelah kelahiran merupakan kontak tubuh kelanjutan yang di 
perlukan bayi untuk mempertahankan perasaan aman pada bayi. Berdasarkan hasil kegiatan selama 3 bulan, Sangat terlihat antusias ibu-ibu balita dalam mengikuti kegiatan penyuluhan dan pelatihan, semua peserta menunjukkan sikap yang positif selama proses kegiatan. Hasil kegiatan menunjukkan adanya peningkatan pengetahuan ibuibu balita tentang pijat bayi dan dari ibu-ibu yang mendapatkan pelatihan pijat bayi

Tingginya pengetahuan ibu tentang pijat bayi, akan memberikan dampak yang positif bagi perkembangan balita. Balita yang mendapatkan pijat bayi selama masa pertumbuhannya pada rentang usia < 1 tahun akan dapat meningkatkan sistem kekebalan tubuh, mengubah gelombang otak secara positif, memperbaikai sirkulasi darah dan pernafasan, meransang fungsi pencernaan serta pembuangan, meningkatkan kenaikan berat badan, mengurangi depresi serta ketegangan, meningkatkan kesiagaan, membuat tidur lelap, mengurangi rasa sakit, mengurangi kembung dan kolik (sakit perut), meningkatkan hubungan batin antara orang tua dan bayinya (bonding), dan meningkatkan volume air susu ibu (Roesli,2009), namun peningkatan pengetahuan tersebut tidak didukung dengan prilaku ibu dalam memijat bayi dirumah, hanya $50 \%$ melakukan pijat bayi dirumah.

Hasil penelitian Sunarsih (2010), menunjukkan adanya pengaruh pijat bayi terhadap kenaikan berat badan bayi umur 0 - 3 bulan di BPS Saraswati Sleman Yogyakarta tahun 2010, rata-rata kenaikan berat badan bayi pada kelompok eksperimen adalah 790 gram dan rata-rata kelompok kontrol adalah 613 gram dengan nilai $t$ hitung $(6,221)$ dan $t$ tabel $(1,753)$ dengan sig.(2 - tailed) 0,000 atau nilai p lebih kecil dari 0,05. Berdasarkan hasil penelitian ini harusnya peningkatan pengetahuan ibu diikuti dengan kesadaran yang tinggi pula. Sehingga manfaat pijat bayi dapat meningkatkan tumbuh kembang bayi.

\section{BAB 4. KESIMPULAN DAN SARAN}

\section{A. Kesimpulan}

Dari kegiatan pengabdian masyarakat ini dapat disimpulkan bahwa :

1. Pengetahuan kader dan ibu balita tentang Pijat bayi adalah meningkat

2. Kader dan ibu balita telah mampu melakukan pijat bayi secara mandiri

\section{B. Saran}

Mengingat besarnya manfaat kegiatan pengabdian pada masyarakat ini, maka selanjutnya perlu :

1. Mengadakan kegiatan serupa pada kelompok ibu balita pada tempat yang berbeda

2. Kepada pihak puskesmas, untuk dapat menjadikan kegiatan pijat bayi ini menjadi kegiatan rutin di Posyandu

3. Meningkatkan motivasi ibu untuk mau melakukan pijat bayi secara rutin dan berkesinambungan

\section{DAFTAR PUSTAKA}

Roesli, Utami. (2009). Pedoman Pijat Bayi. Jakarta: PT. Trubus Agriwidya.

Roesli, Utami. (2008). Pedoman Pijat Bayi

Prematur \& Bayi Usia 0-3 Bulan. Jakarta: PT. Trubus Agriwidya. 
Evaluasi Program Keluarga Berencana Nasional Kecamatan Bukit Raya. (2013). UPTB Pemberdayaan Bukit Raya.

Yanti, \& Eko Nurul. (2010). Etika Profesi dan Hukum Kebidanan. Yogyakarta: Pustaka Rihama.
Chomaria, Nurul. (2011).Paduan

Terlengkap Perawatan Bayi Baru. Surakarta: Ziyad Visi Media.

Profil Kecamatan Bukit Raya. (2014). Kecamatan Bukit Raya.

Soetjiningsih. (2012). Tumbuh kembang Anak. Jakarta: Penerbit Buku Kedokteran 